\title{
HEPATITIS B AND C IN DENTISTRY
}

Assya Krasteva ${ }^{1}$, Vladimir E. Panov ${ }^{2}$, Maria Garova ${ }^{1}$, R. Velikova ${ }^{1}$, Angelina Kisselova $^{1}$, Zahariy Krastev ${ }^{3}$

1) Faculty of Dental Medicine, Sofia

2) Bulgarian Academy of Science, Sofia

3) Medical University, Sofia

\section{SUMMARY}

Viral hepatitis is a major public health problem, occurring endemically in all areas of the world. The prevalence of the disease is influenced by numerous factors which may be able to modulate its onset. The presence of HCV-RNA in saliva provides a biological basis for saliva as a possible source of $\mathrm{HCV}$ infection, although it does not necessarily imply transmission. Lock and coworkers (2006) demonstrates a contamination with HCV-RNA of a considerable portion of toothbrushes used by hepatitis $\mathrm{C}$ patients. Dentists were in a high risk of contracting this disease due to the procedures and instruments of dental treatment.

Key words: dentistry, hepatitis B and C, oral cavity
Patients with liver disorders are of significant interest to the dentist because liver plays a vital role in metabolitic function, including the secretion of bile needed to fat absorption, conversion of sugar to glycogen, excretion of bilirubin, a waste product of hemoglobin metabolism. Impairment of liver function can lead to abnormalities of the metabolism of amino acid, protein, carbohydrates and lipid. Many biochemical function performed by the liver, such as synthesis of coagulation factors and drug metabolism, may be adversely affected.

Viral hepatitis is the most common liver disorder and is a major public health problem, occurring endemically in all areas of the world. The prevalence of the disease is influenced by numerous factors which may be able to modulate its onset.

Table 1. Characteristic of Hepatitis B virus (HBV) and Hepatitis C virus(HCV)

\begin{tabular}{|c|c|c|}
\hline & HBV & HCV \\
\hline Family and types & heapadnavirus & Flavivirus \\
\hline Incubation & 45-180days; $x$ 75days & 14-180 days; $x 50$ days \\
\hline Main route of transmission & parenteral, sexual contact, oral fluid & parenteral, sexual contact, oral fluid ?? \\
\hline Diagnosis & $\begin{array}{l}\cdot \text { HbsAg (infectious) } \\
\cdot \text { AntiHBs (recovery) } \\
\cdot \text { AntiHB cor total( } \operatorname{IgM}+\operatorname{IgG}) \\
\cdot \text { AntiHBc(acute, persistently infected } \\
\text { or previously infected non-protective) } \\
\cdot \text { HBeAg(infectious) } \\
\cdot \text { AntiHBeAg (clearing/ cleared infection) } \\
\cdot \text { HBV DNA(infectivity) }\end{array}$ & $\begin{array}{l}\cdot \text { AntiHCV (previous infection) } \\
\cdot \text { HCV RNA (infectivity) }\end{array}$ \\
\hline Chronic carrier state & $\begin{array}{l}.90 \% \text { risk of becoming chronic carrier } \\
\text { with different stage of chronic liver } \\
\text { disease if infected as neonate; } \\
\cdot 25-50 \% \text { risk of becoming carrier } \\
\text { if infected as infant; } \\
\cdot 5-10 \% \text { risk of becoming carrier if } \\
\text { infected as adult }\end{array}$ & Risk of becoming carrier is $70-80 \%$. \\
\hline
\end{tabular}




\begin{tabular}{|c|c|c|}
\hline Complication of the liver & $\begin{array}{l}\text { Increase risk of liver cirrhosis and } \\
\text { hapatocellular carcinoma (HCC) after } \\
25-30 \text { years of infection }\end{array}$ & $\begin{array}{l}\text { 10fold increase risk of liver cirrhosis } \\
\text { 1-5\% of carriers develop HCC by } \\
20 \text { years-the risk of HCC with chronic } \\
\text { HCV exceeds risk with chronic HBV. } \\
\text { Дори и носител само на onti cor total }\end{array}$ \\
\hline $\begin{array}{l}\text { Immunization } \\
\text { Passive }\end{array}$ & - Hepatitis B immune globulin & - Not available \\
\hline Active & - Recombivax, Engerix and Twinrix & - Not available \\
\hline Associated clinical syndromes & Epstein-Barr virus & $\begin{array}{l}\text { Cryoglobulinemia, malignant lymphoma, } \\
\text { Sjogren's syndrome and } \\
\text { oral lichen planus. }\end{array}$ \\
\hline
\end{tabular}

Legend:

- HBsAg - the hepatitis B surface antigen

- AntiHBs - the antibody responsible for clearing the infection and signaling long-term immunity

- AntiHBc - hepatitis B core antigen

- $\mathrm{HBeAg}$ - hepatits B early antigen

- AntiHB cor total - IgM+IgG antibody

\section{Hepatitis $B$ and $C$ in oral cavity}

HBV infection is the most important infectious occupational hazard in the dental profession.

A number of reports suggest :

- a significantly higher incidence of HBV among dental staff

- a higher rates of HBV especially oral surgeons, periodontists and endodontists

Vectors of infection with HBV in dental practice are: blood, saliva and nasopharyngeal secretions (Mori et al. 1984). In intraorally, the greatest concentration of hepatitis B infection is the gingival sulcus (Itharatana et al. 1988). Also periodontal disease, severity of bleeding and bad oral hygiene were associated with the risk of HBV.

In Egypt patients with periodontal disease showed higher detectability rate of $\mathrm{HBsAg}$, anti $\mathrm{HBc}$, anti $\mathrm{HCV}$ or both anti $\mathrm{HCV}$ and/or anti $\mathrm{HBc}$ in whole unstimulated saliva than the controls (Farghaly et al. 1998).

No undisputed case of HCV saliva transmission has been documented.

However, the existence of other routes of transmission is possible.

- HCV-RNA has been detected in saliva and in salivary glands from patients with sialadenitis (Arrieta et al.2001; Toussirot et al. 2002).

- Most HCV patients (77\%) had higher HCV RNA levels in their gingival sulcus than in their saliva (Suzuki et al.2005)

Leao et al. (2006) found HCV-RNA in a toothbrushes by hepatitis $\mathrm{C}$ patients. This fact could be a theoretical risk of infection by sharing these objects by their household members
Dental Management

Most of dentist were unwilling to treat virus-infected persons.

Medical consideration - patients with viral hepatitis:

- all patient with a history of hepatitis must be managed as they are potentially infectious

- the American Dental Association strongly recommend that all dental health care workers receive vaccination against hepatitis $B$

- no dental treatment other than urgent care (absolutely necessary work) should be rendered for a patient with acute viral hepatitis

- aerosols should be minimized and drugs metabolized in the liver avoided as much as possible (table 2 ) in patients with liver cirrhosis prothrombine time increase, platelet decreased - if surgery is necessary a preoperative evaluation should be obtained.

Table 2. Dental drugs metabolized primary by the liver

\begin{tabular}{|l|}
\hline $\begin{array}{l}\text { Local anesthetics (appear safe for use during liver disease } \\
\text { when used in appropriate amounts) }\end{array}$ \\
\hline$\cdot$ Lidocaine \\
$\cdot$ Mepivacaine \\
$\cdot$ Prilocaine \\
$\cdot$ Bupivacaine \\
\hline Anelgesics \\
\hline$\cdot$ Aspirin* \\
$\cdot$ Codein** \\
$\cdot$ Ibuprofen* \\
\hline
\end{tabular}




\begin{tabular}{|c|}
\hline$\cdot$ Acetaminophen \\
\hline Sedatives \\
\hline$\cdot$ Diazepam $* *$ \\
$\cdot$ Barbiturates $* *$ \\
\hline Antibiotics and Chimioterapevtics \\
\hline Ampicillin \\
Tetracycline \\
Metronidazole $* * *$ \\
Vancomycin*** \\
\hline
\end{tabular}

\section{Legend:}

* limit dose or avoid if sever liver disease (active hepatitis and cirrhosis) or hemostatic abnormalities present

** limit dose or avoid if sever liver disease (active hepatitis and cirrhosis) or encephalopathy present, or taken with alcohol

*** avoid if sever liver disease (active hepatitis and cirrhosis) present

Recommendation to dental practitioners

- HBV vaccination for all clinical staff - 0, 1, 6 month

- one month later - test the HBV immunity - anti HBs (only $80 \%$ persons become immune. If the anti HBs titre is low - a consultation with hematologist is recommended and another vaccination program is needed)

- retest for anti HBs every 4 years

- use of infection control manuals and post-exposure protocols

- hand washing before treating patients

- routine use of gloves and protective eyewear

- using masks and uniforms to protect against splatter of blood and saliva

- heat-sterilizing hand pieces between patients

- biological monitoring of heat sterilizers

- turbine and individuals instruments for every patients

- all patient with a history of viral hepatitis must be managed as though they are potentially infectious.

Conclusion

Dentists were in a high risk of contracting this disease due to the procedures and instruments of dental treatment.

Dentists and their staff should know well the risk of infection from their patients, the risk of cross-infection between patients, and the risk of infecting each other.

\section{REFERENCES:}

1. Arrieta JJ,Rodrhguez-Icigo E, Ortiz-Movilla N, Bartolomй J, Pardo M, Manzarbeitia F, Oliva H, Маснаs DM, Carreco VAm J Pathol. In situ detection of hepatitis $\mathrm{C}$ virus RNA in salivary glands. 2001 Jan;158(1):259-64.

2. Farghaly AG, Mansour GA, Mahdy NH, Yousri A. Hepatitis B and $\mathrm{C}$ virus infections among patients with gingivitis and adult periodontitis: seroprevalence and public health importance. Egypt Public Health Assoc. 1998;73(5-6):707-35.

3. Itharatana K.Viral hepatitis B infection. Transmission and prevention for dentists J Dent Assoc Thai. 1988
Jul-Aug;38(4):180-7.

4. Leao JC, Teo CG, Porter SR. HCV infection: aspects of epidemiology and transmission relevant to oral health care workers.Int J Oral Maxillofac Surg. 2006 Apr;35(4):295-300. Epub 2006 Feb 17.

5. Lock G, Dirscherl M, Obermeier F, Gelbmann CM, Hellerbrand C, Knцll A, Schцlmerich J, Jilg W. Hepatitis C contamination of toothbrushes: myth or reality?Viral Hepat. 2006 Sep;13(9):571-3.

6. Mori M. Status of viral hepatitis in the world community: its incidence among dentists and other dental personnel. Int Dent J. 1984 Jun;34(2):115-21.

7. Suzuki T, Omata K, Satoh T, Miyasaka T, Arai C, Maeda M, Matsuno T, Miyamura T. Quantitative detection of hepatitis $\mathrm{C}$ virus (HCV) RNA in saliva and gingival crevicular fluid of HCV-infected patients.J Clin Microbiol. 2005 Sep;43(9):4413-7.

8. Toussirot E, Le Нuйdй G, Mougin C, Balblanc JC, Bettinger D, Wendling D.J Rheumatol. Presence of hepatitis C virus RNA in the salivary glands of patients with Sjцgren's syndrome and hepatitis C virus infection 2002 Nov;29(11):2382-5.

Address for correspondence:

Asya Krasteva

Department of Oral Diagnostic and Maxillofacial Radiology, Faculty of Dental Medicine, Medical University of Sofia,

1, Georgi Sofiiski Str., Sofia, Bulgaria

E-mail: asyakrasteva@abv.bg, 